\section{ノ- r}

[Nippon Nōgeikagaku Kaishi

Vol.61, No. 12, pp.1589 1591, 1987]

\section{グルタミン酸生産菌 Klebsiella aerogenes}

19-35 における 2-オキソグルタル酸による グルタミン酸脱水素酵素の阻害

浅田芳宏, 金原康久, 田村恭子 (茨城大学農学部農芸化学科)

昭和 62 年 6 月 8 日受理

Inhibition of Glutamate Dehydrogenase by 2 -Oxoglutarate (OGA) in

Klebsiella aerogenes 19-35,

a Glutamate-Producing Bacterium

Yoshihiro ASADA, Yasuhisa KINBARA and Yasuko TAMurA

Department of Agricultural Chemistry,

Faculty of Agriculture, Ibaraki University, 3998, Ami-machi, Inashiki-gun, Ibaraki-ken 300-03

The enzymatic properties of partially purified glutamate dehydrogenase (GDH) from $K$.aerogenes 19-35 were investigated. It was found that GDH, responsible for reductive amination, was subject to substrate inhibition and product inhibition. The substrate inhibition was specific for OGA. In oxidative deamination, no substrate inhibition was observed, although product inhibition occurred. The enzyme was inhibited by malate, fumarate and succinate in biosynthetic reaction, although these organic acids stimulated the activity of GDH in degradative reaction.

(Received June 8, 1987)

グルタミン酸生産菌は生育にビオチンを要求し、グ ルタミン酸生産むまた培地中のビオチン量で調節され る(1,2)。・タルミン酸生産菌のグルタミン酸生合成の最 終段階では，グルタミン酸脱水素醅素 (GDH) に上る還 元的アミノ化反応で 2-オキソグルタル酸 (OGA) へア ソモニアが取り込まれる.これらビオチン要求菌株の GDH の性質について詳細な研究が行学れている(1て5). 一方，生育にビオチンを要求しないKlebsiella aero- genes 19-35 がグルタミン酸を生産することを見出し た ${ }^{(6)}$. ビオチン非要求性グルタミン酸生産菌の GDH の 性質は不明である。著者らは供試菌の GDH の性質につ いて部分精製酵素で検討した結果，2ーオキソグルタル酸 による GDH 活性阻害を見出した。

0.05M リン酸緩衝夜（pH 7.5）で調制しだ細胞抽出液 を $30 \sim 50 \%$ 飽和硫安で分画し，続いて $55^{\circ} \mathrm{C} ， 5$ 分間加 熱処理後，その遠心上澄液を $50 \%$ 飽和硫安で再分画し た. その後, $0.05 \mathrm{M}$ リン酸緩衝液 $(\mathrm{pH} 7.5)$ で平壃化し た Bio-Gel A-0.5 m カラム $(24 \times 800 \mathrm{~mm})$ をいて分 画し，活性区分を同し緩衝液で平衡化したDEAE せル ローズカラム $(22 \times 200 \mathrm{~mm})$ に吸着させ, 終濃度 $1 \mathrm{M}$ の $\mathrm{NaCl}$ を含む $0.05 \mathrm{M}$ リン酸緩衙液 $(\mathrm{pH} 7.5)$ て浱度 勾配法で分画した. その結果，約 $5 \%$ の収率で約 200 倍に精製した䤃素標品を得た. GDH 活性測定は椎尾ら の用いた方法に準じて行った(4). 蛋白の測定は Lowry らの方法で测定した(7).

供試菌の GDH によるグルタミン酸の合成反応は補 醉素として NADPH を要求した。 また，至適 $\mathrm{pH}$ は 7.5 であった，本醉素の OGA に対する基質飽和曲線を Fig. 1 に示した. OGA $2.5 \mathrm{mM}$ で GDH は最大活性を 示したが，OGA 濃度が増大するにつれ活性は減少した。 一方の基質であるフンモニフではこのような基質增大に 伴ら活性の減少は認められなかった（Fig.2)。これらの 結果は K. aerogenes 19-35 の GDH が OGA によって 特異的に阻害を受ける，いわゆる基質阻害現象を明らか にした，OGA によるGDH の基質阻害現象は茶の根か ら分離した GDH で見出されているだけでタ)，グルタミ ン酸生産菌は子ち万ん，非生産菌，上くにKlebsiella 属でも見出されていない、乹.

本䤃素の $\mathrm{NH}_{4} \mathrm{Cl}, \mathrm{NADPH}$ に対するみかけの $\mathrm{Km}$ は $2.9 \times 10^{-3} \mathrm{M}, 4.4 \times 10^{-5} \mathrm{M}$ で, OGA へのみかけ上の $K m$ は $4 \times 10^{-3} \mathrm{M}$ であった，また，反応生成物である $\mathrm{NADP}$, クルタミン酸によるGDH 活性阻害（生成物阻 害）も認められた，この場合，GDH 活性の50\% 阻害 は NADPが $0.4 \mathrm{mM}$ で,グルタミン酸が $100 \mathrm{mM}$ で得 られた。阻害形式は OGA に対してNADPで混合型, グルタミン酸で拮抗型であった.

他方，本酳素のグルタミン酸分解反応は至適 $\mathrm{pH}$ を 9.0 に有し, その活性は合成反応の約 $1 / 5$ と弱い活性で ある.グルタミン酸に対する飽和曲線は双曲線型を示 し、みかけの $\mathrm{Km}$ 值は $4.2 \times 10^{-3} \mathrm{M}$ であった NADP 


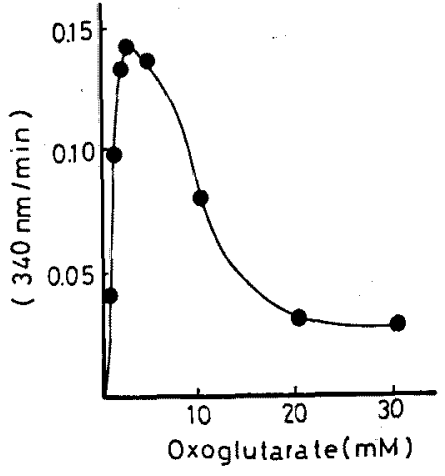

Fig. 1. Saturation Curve for the Biosynthetic Reaction of Glutamate Dehydrogenase from Klebsiella aerogenes 19-35. Assay system consisted of ; $80 \mathrm{mM}$ phosphate buffer $(\mathrm{pH} \mathrm{7.5)}$, $20 \mathrm{mM} \mathrm{NH}_{4} \mathrm{Cl}, 0.15 \mathrm{mM} \mathrm{NADPH}, 2$-oxoglutarate varied, $10 \mu \mathrm{g}$ enzyme protein.

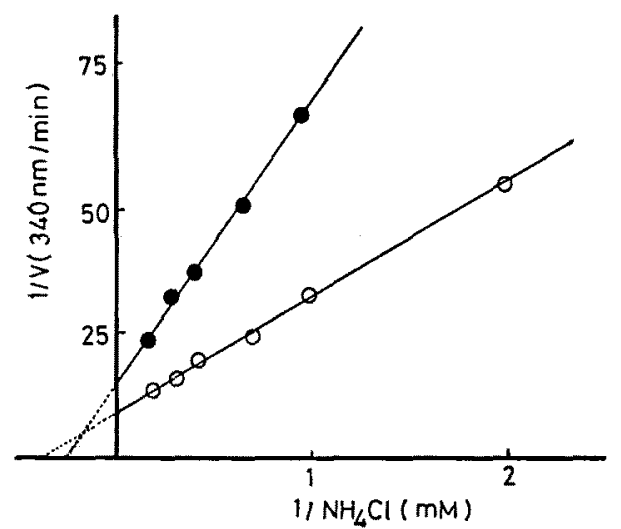

Fig. 2. Double Reciprocal Plots of the Reaction Velocity against Ammonium Chloride Concentration at the OGA Concentration of $2.5 \mathrm{mM}$ (O) and $25 \mathrm{~mm}$

に対するみかけの $\mathrm{Km}$ 值は $5.3 \times 10^{-5} \mathrm{M}$ であった。 た，反応生成物，NADPH，OGA， $\mathrm{NH}_{4} \mathrm{Cl}$ による阻害は すべてにおいて諰められ，その $50 \%$ 阻害は持のおの, $0.08 \mathrm{mM}, 3 \mathrm{mM}, 2 \mathrm{mM}$ で得られた.

OGA の代謝に関連する物質として，TCA サイクルの 有機酸等の本酵素活性に及ぼす影響を検討した結果を Table I K示した，合成反応では Lーリンゴ酸が $50 \%$ 阻 害と最大值を示し，以下、フマール酸，コハク酸，才ギ ザロ酿酸と続き，オギザロ酢酸で約 $20 \%$ の阻害であっ た (Table I). Lーリンゴ酸は OGA に対して拮抗的に阻

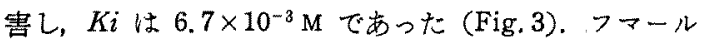

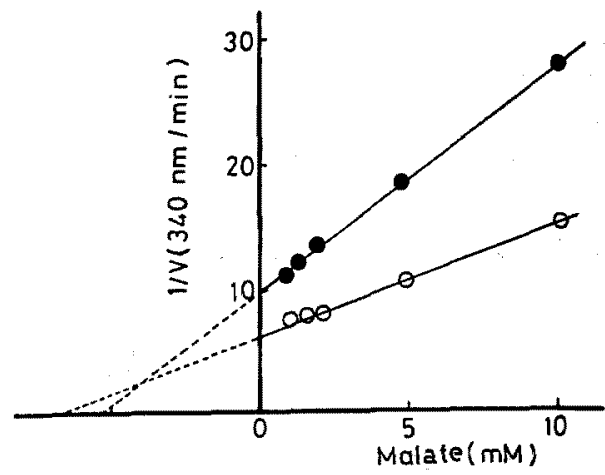

Fig. 3. Inhibition of Glutamate Dehydrogenase by Malate. 2-Oxoglutarate; $1 \mathrm{mM}(\bullet), 2.5 \mathrm{mM}$ (O).

Table I. Effects of Various Compounds on the Activity of Glutamate Dehydrogenase. Assay system (biosynthetic reaction) consisted of ; $80 \mathrm{mM}$ phosphate buffer (pH 7.5), $20 \mathrm{mM}$ $\mathrm{NH}_{4} \mathrm{Cl}, 0.15 \mathrm{mM}$ NADPH, $3 \mathrm{mM} 2$-oxoglutarate, $10 \mu \mathrm{g}$ protein.

Assay system (degradative reaction) consisted of ; $100 \mathrm{mM}$ Tris-HCl buffer ( $\mathrm{pH} \mathrm{9.0),}$ $20 \mathrm{mM}$ glutamate, $0.1 \mathrm{mM} \mathrm{NADP}, 10 \mu \mathrm{g}$ protein.

\begin{tabular}{lcc}
\hline \multicolumn{1}{c}{ Addition } & \multicolumn{2}{c}{ Relative activity } \\
\cline { 2 - 3 } & $\begin{array}{c}\text { Biosynthetic } \\
\text { reaction }\end{array}$ & $\begin{array}{c}\text { Degradative } \\
\text { reaction }\end{array}$ \\
\hline None & 100 & 100 \\
Citrate & 107 & 22 \\
cis-Aconitate & 95 & 128 \\
DL-Isocitrate & 100 & - \\
Succinate & 75 & 141 \\
Fumarate & 65 & 140 \\
L-Malate & 50 & 134 \\
Oxalacetate & 80 & - \\
Glyoxylate & 92 & 67 \\
Pyruvate & 110 & 123 \\
Acetyl CoA & 100 & 84 \\
Phosphoenolpyruvate & 100 & 10 \\
NADP & 50 & - \\
NADPH & - & 40 \\
2-Oxoglutarate & - & 17 \\
L-Glutamate & 90 & - \\
Ammonium chloride & - & 20 \\
\hline
\end{tabular}

\& $10 \mathrm{mM}, \mathrm{NADP} ; 0.5 \mathrm{mM}, \mathrm{NADPH} ; 0.1 \mathrm{mM}$, acetyl CoA.

酸、コハク酸でもはぼ同様の結果を得た，他方，分解反 応江対し，タェン酸，ホスホエノールピルビン酸は阻贵 的に, コハク酸、フマール酸，Lーリンゴ酸は促進的に作 
用した (Table I). B. flavum の GDH の合成反応はク エン酸、シスアコニット酸，DL-イソクェン酸で $20 \%$ 活 性促進を受け，さらに分解反応はフマール酸で $25 \%$ 活 性促進を受け，全体として TCA サイクルの有機酸によ る活性の阻害は認められていない(5)。したがって，供試 菌の GDH は OGA を初めとして, TCA サイクルの酸 による活性の阻害的調節を受ける点で他の菌に比べ異な っていることが明らかになった，GDH の OGA Kよる 負の制御は供試菌に批ける Lーグルタミン酸生痤に矛盾 することで, 今後，Lーグルタミン酸生成機構と本酵素の 役割が問題となる。

（1）飯塚 広，阿部重雄，高山㯬一郎：「フミノ酸 発醅」上巻，木下祝郎占編，共立出版，1972， p.3.

（2）木下祝郎，田中勝宣：「>ミノ酸発醭」下巻,
山田浩一ら編, 共立出版, 1972, p. 1 .

(3) K. Oshima, K. Tunoda and S. Kinoshita: Agric. Biol. Chem., 28, 714 (1964).

(4) I. Shiio and K. Ujigawa : $J$. Biochem., 84, 647 (1978).

(5) I. Shiio and H. Ozaki : J. Biochem., 68, 633 (1970).

（6）高村義親，藤井義昭，植村定治郎：Amino Acids, 7, 35 (1963).

(7) O. H. Lowry, N. J. Rosebrough, A. L. Farr and R. J. Randall : J. Biol. Chem., 193, 265 (1951).

(8) T. Takeo : Agric. Biol. Chem., 43, 2257 (1979).

(9) E. L.Smith, B. M. Austen, K. M. Blumenthal and J. F. Nyc: "Glutamate Dehydrogenase," In The Enzymes, Vol. XI, ed. by P. D. Boyer, 1975, Academic Press, New York, p. 293. 